\title{
Trophic Trait Evolution Explains Variation in Nutrient Excretion Stoichiometry among Panamanian Armored Catfishes (Loricariidae)
}

\author{
Eric K. Moody ${ }^{1,2, *}$, Fernando Alda ${ }^{3}{ }^{\circ}$, Krista A. Capps ${ }^{4}$, Oscar Puebla ${ }^{5,6}$ and \\ Benjamin L. Turner 6 \\ 1 Arizona State University School of Life Sciences, Tempe, AZ 85281, USA \\ Department of Ecology, Evolution, and Organismal Biology, Iowa State University, Ames, IA 50011, USA \\ 3 Department of Biology, Geology, and Environmental Science, Chattanooga, \\ University of Tennessee at Chattanooga, TN 37403, USA; Fernando-Alda@utc.edu \\ 4 Savannah River Ecology Laboratory, University of Georgia, Aiken, SC 29802 USA; kcapps@uga.edu \\ 5 GEOMAR Helmholtz Centre for Ocean Research Kiel, 24105 Kiel, Germany; opuebla@geomar.de \\ 6 Smithsonian Tropical Research Institute, Apartado 0843-03092, Balboa, Ancon, Panama; turnerbl@si.edu \\ * Correspondence: ekmoody@iastate.edu
}

Received: 1 April 2019; Accepted: 3 June 2019; Published: 5 June 2019

\begin{abstract}
Variation in nutrient excretion rates and stoichiometric ratios (e.g., nitrogen to phosphorus) by consumers can have substantial effects on aquatic ecosystem function. While phylogenetic signals within an assemblage often explain variation in nutrient recycling rates and stoichiometry, the phylogenetically conserved traits that underlie this phenomenon remain unclear. In particular, variation in nutrient excretion stoichiometry across a phylogeny might be driven by phylogenetic patterns in either diet or body stoichiometry. We examined the relative importance of these traits in explaining variation in nutrient recycling rates and stoichiometry in a diverse family of Neotropical-armored catfishes, Loricariidae, in Panamanian streams. We found significant variation in nutrient mineralization traits among species and subfamilies, but variation in nutrient excretion stoichiometry among species was best explained by trophic position rather than body stoichiometry. The variation in trophic position among Panamanian species was consistent with variation in the trophic niche of their genera across South America, suggesting that phylogenetic patterns underpin the evolution of trophic and nutrient excretion traits among these species. Such geographical variation in nutrient mineralization patterns among closely related species may be common, given that trophic variation in fish lineages occurs widely. These results suggest that information on trophic trait evolution within lineages will advance our understanding of the functional contribution of animals to biogeochemical cycling.
\end{abstract}

Keywords: nutrient recycling; Neotropical stream; nitrogen; phosphorus; suckermouth catfish

\section{Introduction}

Consumer-driven nutrient recycling and storage can substantially alter ecosystem function in aquatic ecosystems [1-3]. As a result, there has been considerable interest in understanding what drives patterns in the rates and ratios of key nutrients such as nitrogen $(\mathrm{N})$ and phosphorus $(\mathrm{P})$ recycled by consumers. The N:P ratio at which consumers recycle nutrients is thought to vary with body N:P, $\operatorname{diet} \mathrm{N}: \mathrm{P}$, and the maximum accumulation efficiency of $\mathrm{N}$ or P [4]. Variance in any or all of these three parameters could explain interspecific differences in nutrient recycling, yet most studies have focused on consumer body stoichiometry (e.g., [5-8]). Indeed, the N:P ratio of consumer body tissues and consumer body mass have been identified as predictors of the rate and stoichiometric ratio of nutrient 
recycling in large-scale studies of entire consumer assemblages [6,9]. On the other hand, variation in nutrient mineralization stoichiometry within species is driven largely by variation in diet and consumption rate [10-12]. The primary factors driving variation in consumer-driven nutrient recycling therefore vary with the scale of biological organization being studied, yet the relative importance of factors such as consumer body stoichiometry, diet, and assimilation efficiency at intermediate scales such as among species within a family remains unclear.

In community-scale studies, taxonomic family often predicts consumer-driven nutrient recycling due to family-scale patterns in body stoichiometry and/or dietary habits (e.g., [5,6,13]), which supports the hypotheses that body stoichiometry and trophic niche are phylogenetically conserved traits among families (e.g., [14,15]). However, phylogenetic conservatism of ecological traits can vary substantially among traits and lineages $[16,17]$. To predict patterns in consumer-driven nutrient dynamics among distantly-related species, it is important to understand the degree to which ecological traits are conserved within families. Thus, a weaker phylogenetic signal for body stoichiometry than for trophic niche in a particular lineage would suggest that variation in body stoichiometry should play a larger role in driving variation in nutrient mineralization stoichiometry among species of that lineage.

To examine whether variation in body stoichiometry and trophic niche can predict excretion ratios among species within a diverse family, we studied these traits in an assemblage of armored catfishes (Loricariidae). Loricariids are a primarily herbivorous group of fishes which reach the northern limit of their native range in Central America [18,19]. Many loricariids are covered with extensive bony plating, placing them among the most P-rich lineages of vertebrates [6,20-22]. These qualities have made loricariids a focus for studies of ecological stoichiometry (e.g., [21,23-25]). However, cryptic dietary [18] and stoichiometric [6] diversity among lineages suggests that this group of fishes is also ideal for testing hypotheses of phylogenetic conservatism in stoichiometric and trophic traits. Variation among genera within assemblages of loricariids may thus illuminate relationships between ecological and evolutionary stoichiometric variation.

To examine interspecific relationships between body and mineralization stoichiometry in loricariids, we focused on species in eastern Panama, where several loricariid genera have colonized the lower portion of Central America $[19,26]$. Panamanian loricariids represent a small fraction $(\sim 22 \%$ of genera and $\sim 2 \%$ of species) of the whole family diversity (26). Nevertheless, this assemblage has been the subject of considerable study, so their diets and distributions are well-known relative to loricariids in other regions [20,27-29]. Further, the primarily herbivorous subfamily Hypostominae and the more trophically diverse subfamily Loricariinae are both represented by several species in Panama. Here, we test the drivers of intrafamilial variation in the rates and stoichiometric ratio of nutrient mineralization with data on the body and excretion stoichiometry of six species of Panamanian loricariids.

\section{Methods}

We collected fishes from 11 streams in three main river basins in eastern Panama: the Bayano, Chagres, and Chucunaque during the dry seasons of 2013 and 2014 (Table 1; Figure 1). Not all species were present or measured in each watershed (Table 2). At each sampling site, we collected water samples for chemical analyses before collecting fishes to characterize geographic variation in nutrient availability to the algae and invertebrates upon which loricariids feed. Most fishes were collected by cast net, but we also collected small numbers by electrofishing and dip nets. To test whether the collection method influenced our results, we compared excretion ratios of Chaetostoma fischeri collected from two rivers within the Bayano watershed, one in which we used a cast net and one in which we electrofished. We found no significant difference between rivers ( $t$-test, $t=0.215, d f=9, p=0.835$ ), suggesting that the collection method did not bias our results. Collected fish were held in aerated buckets of stream water until excretion measurements began. In all cases, excretion measurements were conducted within 2 hours of collection, as excretion rates of loricariids decrease over time after feeding [24]. All collections took place during daylight hours. Although some loricariids feed primarily 
nocturnally [24], prior observations of several target species in one of our study rivers supports our own observations that these species feed diurnally as well (Power 1984). Further, we were most interested in standardizing methods among species and it was not feasible to collect fish at night at all study sites.

Table 1. Dissolved inorganic nitrogen (DIN) and dissolved inorganic phosphate (DIP) concentrations of the sample locations across eastern Panama. Samples were collected during the dry seasons (February-April) of 2013 and 2014.

\begin{tabular}{ccccc}
\hline Site & Watershed & DIN $(\mu \mathrm{g} / \mathrm{L})$ & DIP $(\mu \mathrm{g} / \mathrm{L})$ & N:P (molar) \\
\hline Quebrada Juan & Chagres & 154.6 & 22.8 & 15.0 \\
Grande & Chagres & 262.7 & 20.8 & 28.0 \\
Río Frijoles & Chagres & 319.2 & 46.8 & 15.1 \\
Río Frijolito & Bayano & 118.3 & 21.5 & 12.2 \\
Río Chechebre & Bayano & 118.9 & 54.7 & 4.8 \\
Río Curtí & Bayano & 98.3 & 13.1 & 16.6 \\
Río Mamoní & Bayano & 135.1 & 35.8 & 8.4 \\
Río Piriatí & Chucunaque & 139.2 & 8.1 & 38.1 \\
Quebrada La Hoya & Chucunaque & 144.4 & 14.4 & 22.2 \\
Río Chucunaque & Chucunaque & 172.8 & 29.0 & 13.2 \\
Río Icuanatí & Chucuco & 15.0 \\
Río Tupisa & Chucunaque & 173.5 & 25.6 & \\
\hline
\end{tabular}

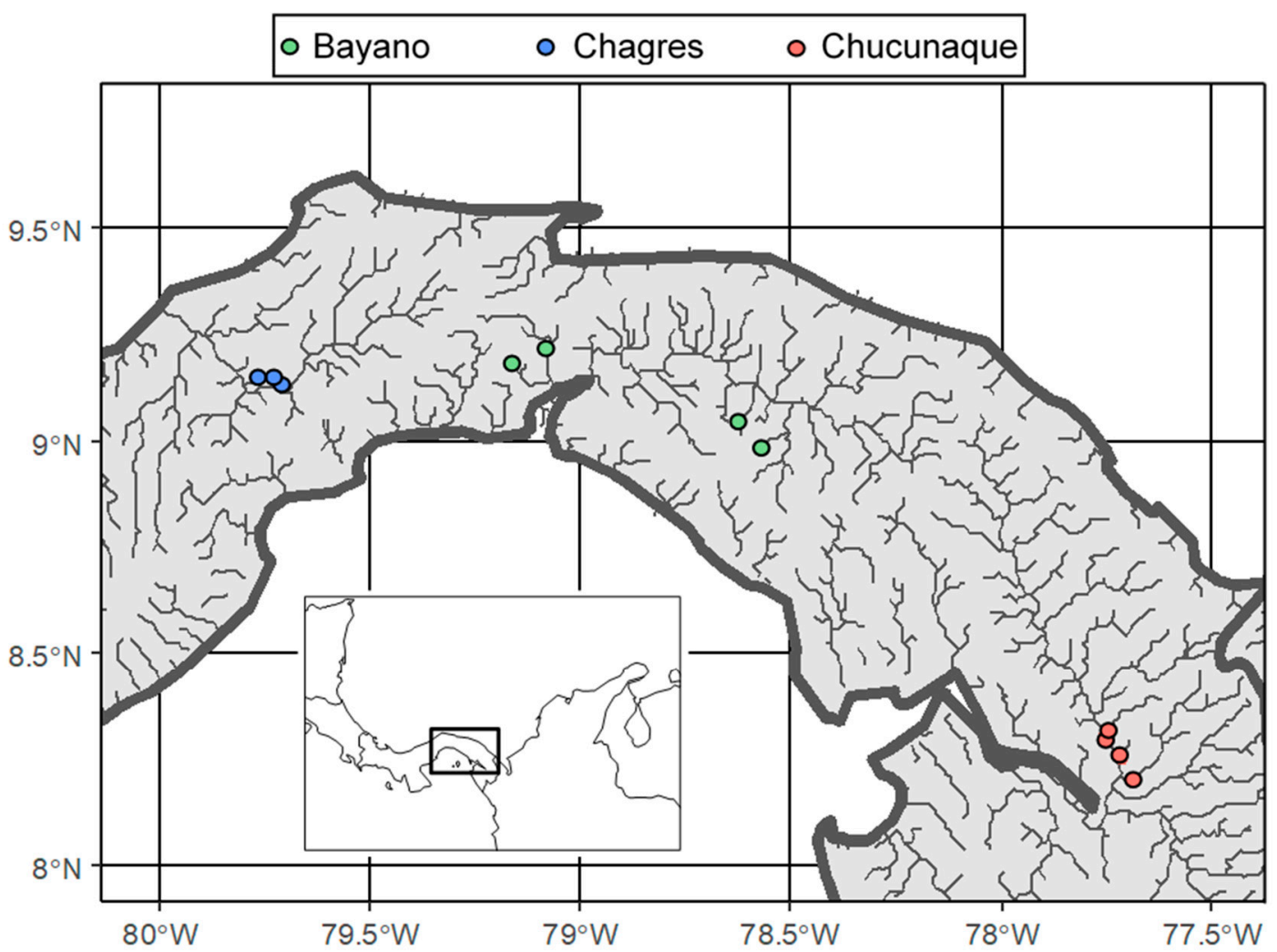

Figure 1. Map of study sites in eastern Panama. Sites are color-coded by the major basin in which they occur. Inset map shows the location of the study sites relative to Panama and surrounding countries. 
Table 2. Number of individuals of each species collected for stoichiometric and isotopic trait sampling in each major watershed. Cells marked " $X$ " indicate that the species was collected within that watershed but not measured in this study while cells marked with "N/A" indicate that the species was not found by us and is not known to occur in that watershed. We also measured nutrient excretion rates of three individuals of Hemiancistrus aspidolepis but omit them from our analyses due to a lack of body stoichiometry data for that species.

\begin{tabular}{cccc}
\hline Species & Bayano & Chagres & Chucunaque \\
\hline Ancistrus chagresi & $\mathrm{N} / \mathrm{A}$ & 2 & $\mathrm{~N} / \mathrm{A}$ \\
Chaetostoma fischeri & 16 & $\mathrm{X}$ & 1 \\
Lasiancistrus caucanus & 4 & $\mathrm{~N} / \mathrm{A}$ & $\mathrm{X}$ \\
Rineloricaria uracantha & $\mathrm{X}$ & 12 & $\mathrm{~N} / \mathrm{A}$ \\
Sturisoma dariense & $\mathrm{X}$ & $\mathrm{N} / \mathrm{A}$ & 10 \\
Sturisomatichthys & $\mathrm{X}$ & $\mathrm{N} / \mathrm{A}$ & 5 \\
citurensis & & & \\
\hline
\end{tabular}

Excretion rates were measured following the protocol described by Small et al. [30]. Briefly, fish were placed into Whirl-Pak bags (Nasco, Fort Atkinson, WI, USA) filled with $1 \mathrm{~L}$ of filtered stream water $(0.45 \mu \mathrm{m}$ pore size filter), incubated in-stream for approximately $1 \mathrm{~h}$, and then samples of the bag water were collected and compared with control bags that did not contain fish. Samples were placed on ice immediately and frozen as soon as possible. For the Chucunaque watershed, samples were placed on ice but were not frozen until 2 days after collection due to lack of electricity at the collection site. All other samples were frozen on the same day of collection. Due to this potential difference in method, we measured $\mathrm{N}$ excreted as both ammonium $\left(\mathrm{NH}_{4}\right)$, the form in which the majority of $\mathrm{N}$ is excreted by fishes, and nitrate/nitrite, the forms into which it may have been converted while kept on ice. As these samples were filtered and filled without headspace, we expected any loss of inorganic $\mathrm{N}$ to other forms to be minimal. After collecting water samples from the bag water, we then euthanized a subset of the fish using clove oil, measured their standard length, dissected their guts, and preserved their bodies in salt for up to 3 days (following [31]). Fish were then oven-dried at $50^{\circ} \mathrm{C}$ for several days to constant mass, then coarsely homogenized using a coffee grinder followed by pulverization in a ball mill. The remainder of the collected fish were preserved in formalin as vouchers and deposited into the STRI Neotropical Fish Collection and the Museo de Biología Marina of the Universidad de Panamá.

We used a Lachat QuikChem Flow Injection Analysis System (Hach Ltd., Loveland, CO, USA) to measure dissolved inorganic phosphate $\left(\mathrm{PO}_{4}\right)$, ammonium $\left(\mathrm{NH}_{4}\right)$, and the combined concentration of nitrate $\left(\mathrm{NO}_{3}\right)$ and nitrite $\left(\mathrm{NO}_{2}\right)$ in excretion and water samples. Dissolved inorganic $\mathrm{N}(\mathrm{DIN})$ was then calculated as the sum of ammonium and nitrate/nitrite. This is less than the total dissolved N, which includes some dissolved organic forms of $\mathrm{N}$, but encompasses the inorganic $\mathrm{N}$ available to primary producers. Homogenized whole fish body samples were analyzed for body $\mathrm{C}: \mathrm{N}$ and stable isotope ratios on a Thermo Delta V Advantage isotope ratio mass spectrometer (Thermo Scientific, Waltham, MA, USA), and for total $\mathrm{P}$ by ignition $\left(550^{\circ} \mathrm{C}\right)$ followed by digestion in $1 \mathrm{M} \mathrm{HCl}$, with $\mathrm{P}$ detection by automated molybdate colorimetry on a Lachat Quikchem 8500 (Hach Ltd., Loveland, $\mathrm{CO}, \mathrm{USA}$ ). We did not extract lipids or perform lipid corrections from stable isotope samples because measured fish $\mathrm{C}: \mathrm{N}$ was near or below the threshold for suggested lipid correction in all species [32]. Thus, we assumed that lipid contents were sufficiently low and similar among species that a correction was unnecessary. Sample sizes of fishes collected for excretion, body stoichiometry, and stable isotope analyses are presented in Table 2.

We calculated the centroid for stable isotope data across all sites following Lujan et al. [18] to visually compare variation among individual species. We then conducted single ANOVAs with Type I sum of squares for each response variable to test whether trophic traits, body stoichiometric traits, and excretion stoichiometric traits differed with body mass and among species and subfamilies as well as watersheds. These fixed effects were included in the models in the order listed based on our predictions of which factors would be most important. As we did not have all trait data from the same individual 
fish, we then used correlation tests to test whether mean excretion $\mathrm{N}: \mathrm{P}$ significantly differed with predictor traits among species. We assessed normality and heteroscedasticity of residuals using Q-Q plots and residuals vs. fitted value plots, respectively, and log-transformed data when assumptions were not met. All statistical analyses were performed in the R computing environment v.3.5.1 [33].

\section{Results}

Dissolved inorganic nitrogen (DIN) ranged from 98.3 to $319.2 \mu \mathrm{g} \mathrm{N} / \mathrm{L}$ while dissolved inorganic phosphate (DIP) ranged from 13.1 to $54.7 \mu \mathrm{g}$ P/L (Table 1). Water chemistry was similar among basins, but streams in the Bayano basin, which were downstream of larger human communities, had lower $\mathrm{N}: \mathrm{P}$ than streams in the other two basins (Table 1). Stream temperatures were consistently between 26 and $30^{\circ} \mathrm{C}$, conductivity was fairly low $(<320 \mu \mathrm{S} / \mathrm{cm})$, and $\mathrm{pH}$ was slightly alkaline (7.5 to 8.0$)$. As the stoichiometric traits we measured in fishes did not vary among watersheds, watershed differences were not considered in further analyses.

There was considerable variation in tissue-stable isotope ratios around the centroid value, with hypostomines varying more in $\delta^{13} \mathrm{C}$ and loricariines varying more in $\delta^{15} \mathrm{~N}$ (Figure 2). We also found significant variation in $\delta^{13} \mathrm{C}$ and $\delta^{15} \mathrm{~N}$ among both species and subfamilies. We subsequently tested for variation in body stoichiometry among species and subfamilies. We found significant variation in body $\% \mathrm{C}\left(\mathrm{F}_{1,39}=4.86, p=0.003\right)$ and $\% \mathrm{~N}\left(\mathrm{~F}_{1,39}=4.13, p=0.007\right)$ among species. Further, body \%C also varied among subfamilies $\left(\mathrm{F}_{1,39}=6.09, p=0.018\right)$, while body $\% \mathrm{~N} \operatorname{did} \operatorname{not}\left(\mathrm{F}_{1,39}=1.84, p=0.182\right)$. In addition, body $\% \mathrm{C}$ increased with body mass $\left(\mathrm{F}_{1,39}=5.62, p=0.023\right)$, but neither $\% \mathrm{~N}$ nor $\% \mathrm{P}$ varied with mass $(p>0.05)$. In fact, body $\% \mathrm{P}$ was relatively high but statistically invariant with the predictors we considered. As a result, body N:P also varied significantly among species $\left(\mathrm{F}_{2,38}=8.60, p<0.001\right)$, but not with any other predictors. The variation among species was primarily driven by the relatively unique stoichiometry of Sturisoma dariense, which was lower in N:P than the other loricariine species and the hypostomine Chaetostoma fischeri.

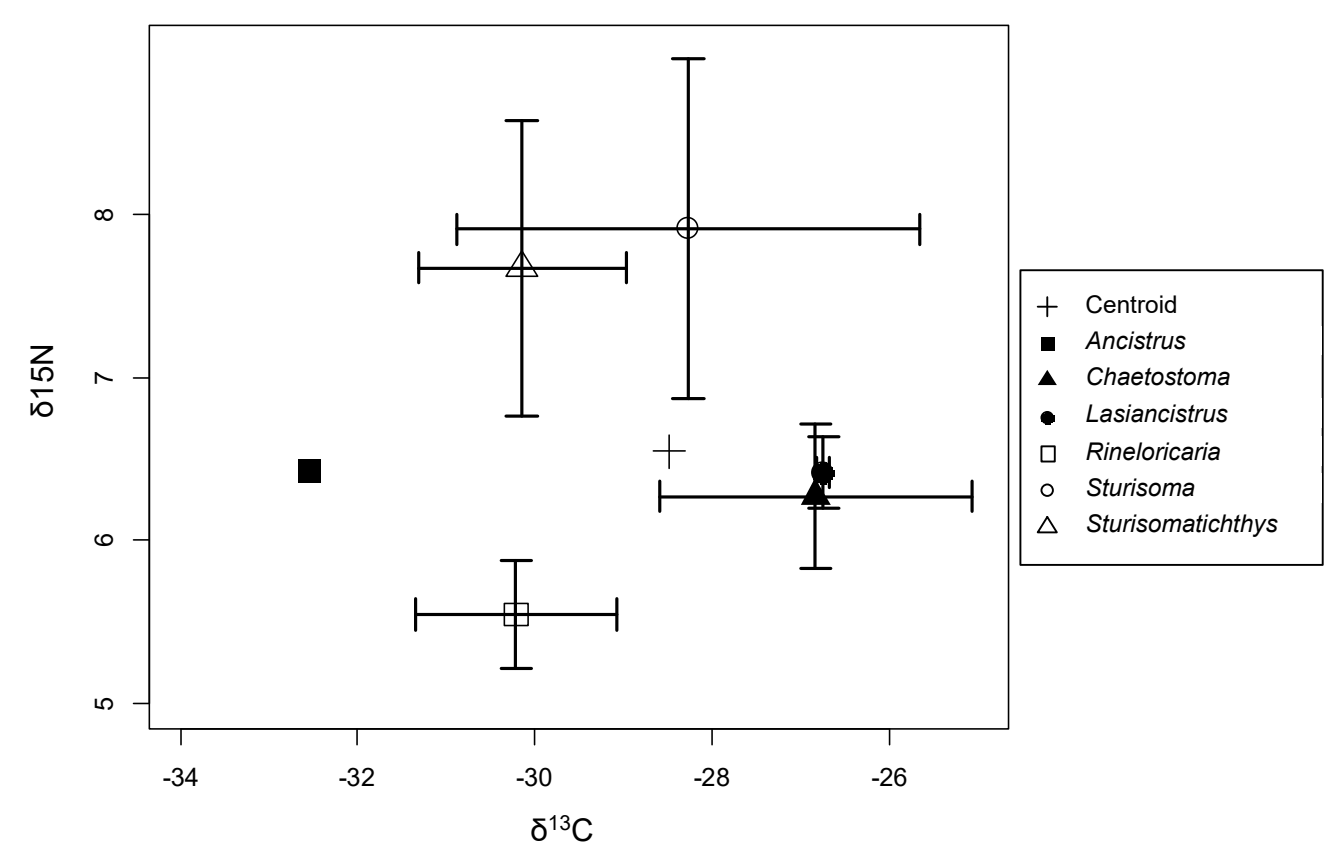

Figure 2. Stable isotope centroids for all data (cross symbol) and individual loricariid taxa averaged across all sampling sites. Dark symbols are genera in Hypostominae, and white symbols are genera in Loricariinae. Error bars represent standard deviation, and sample sizes are listed in Table 2.

Contrary to patterns in body stoichiometry, subfamily was a significant predictor of both $\mathrm{N}\left(\mathrm{F}_{1,27}=13.69, p<0.001\right)$ and $\mathrm{P}\left(\mathrm{F}_{1,27}=18.09, p<0.001\right)$ excretion rates. Specifically, hypostomine 
species excreted both $\mathrm{N}$ and $\mathrm{P}$ at higher rates than loricariine species of a given mass (Figure 3). Notably, species differences within subfamilies were also important in explaining variation in both $\mathrm{N}\left(\mathrm{F}_{4,27}=4.15, p=0.009\right)$ and $\mathrm{P}\left(\mathrm{F}_{4,27}=2.83, p=0.044\right)$ excretion rates. As with individual elemental excretion rates, the stoichiometric ratio of excretion $(\mathrm{N}: \mathrm{P})$ also varied with both subfamily $\left(\mathrm{F}_{1,27}=6.51\right.$, $p=0.017)$ and species $\left(\mathrm{F}_{4,27}=8.25, p<0.001\right)$. Loricariine excretion had greater $\mathrm{N}: \mathrm{P}$ than hypostomine excretion, which was most extremely exemplified by the loricariine $S$. dariense (open circles in Figures 3 and 4$)$.
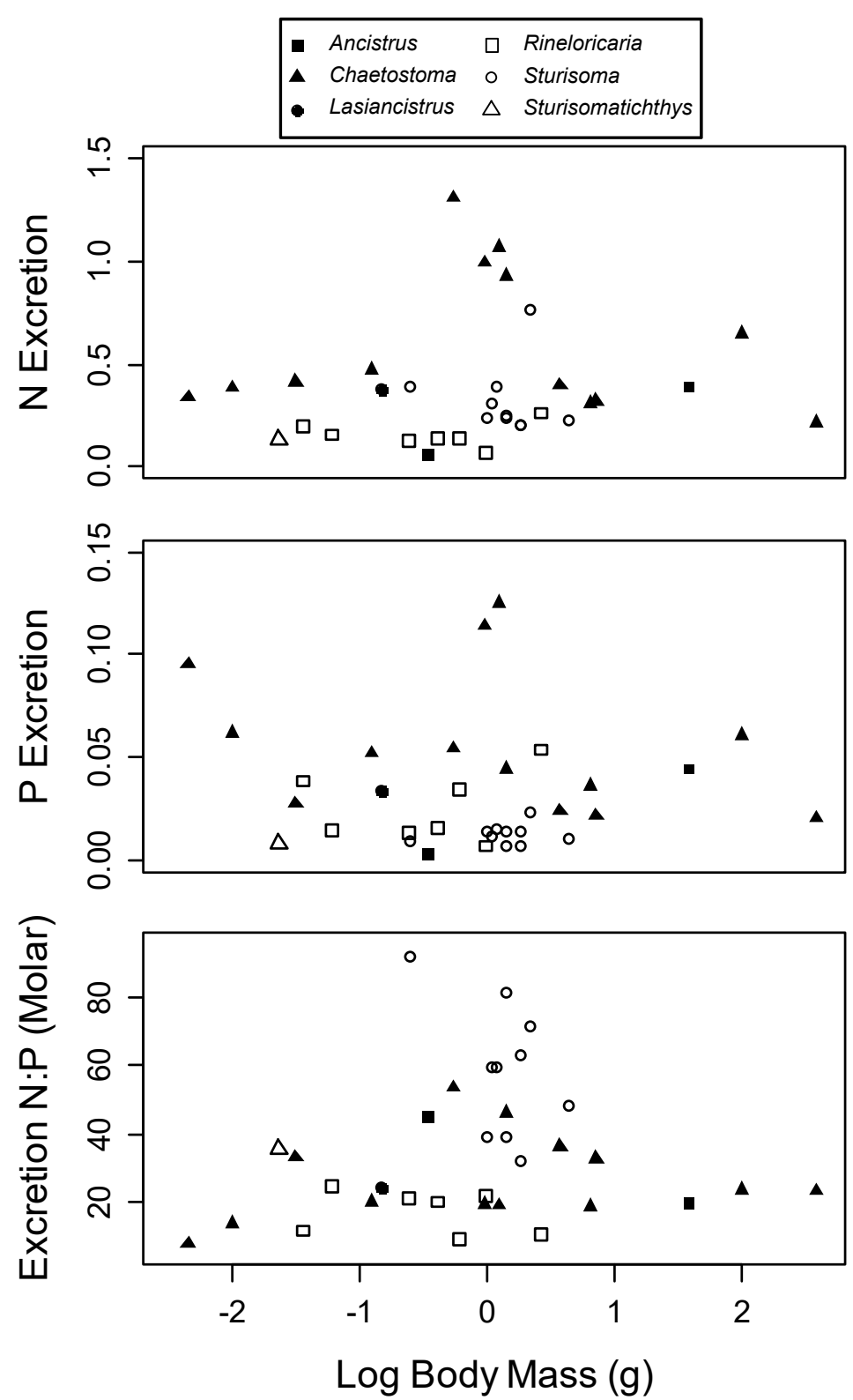

Figure 3. Excretion rates $\left(\mathrm{mg} \mathrm{L}^{-1} \mathrm{hr}^{-1}\right)$ and N:P ratio as a function of body mass for the two subfamilies of Loricariidae measured in this study. Dark symbols are genera in Hypostominae, and white symbols are genera in Loricariinae. All points represent individual fish. 


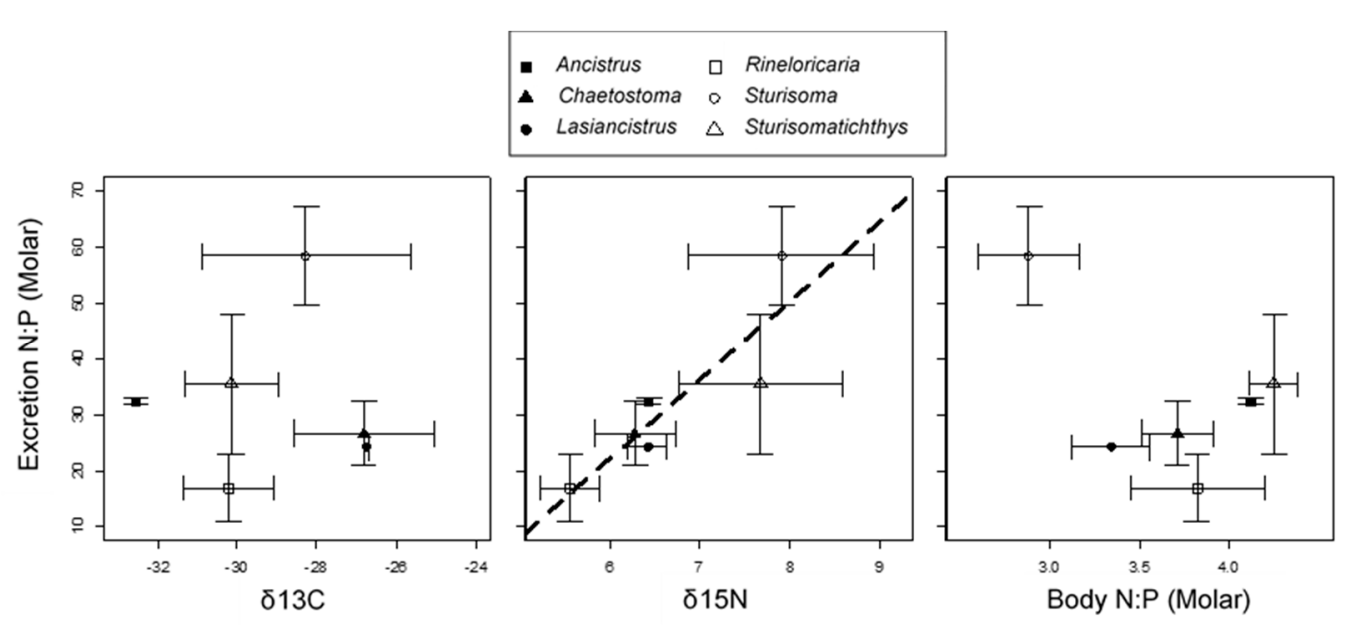

Figure 4. Relationships between excretion N:P and $\delta^{13} \mathrm{C}, \delta^{15} \mathrm{~N}$, and body N:P among species of Panamanian loricariids. Excretion N:P was positively correlated with $\delta^{15} \mathrm{~N}(\mathrm{r}=0.884, p=0.019)$, but not $\delta^{13} \mathrm{C}$ or body N:P. Dark symbols are genera in Hypostominae, and white symbols are genera in Loricariinae. Error bars represent standard deviation.

Finally, we examined species-specific relationships between excretion N:P and trophic niche or body stoichiometry. Not surprisingly, mean excretion N:P was not correlated with mean $\delta^{13} \mathrm{C}(\mathrm{r}=0.022$, $p=0.967)$; yet, mean excretion N:P did vary with mean $\delta^{15} \mathrm{~N}$. Counterintuitively, this correlation was positive ( $r=0.884, p=0.019$; Figure 4$)$, indicating that species feeding on higher trophic levels excreted nutrients at a higher N:P ratio. Also, somewhat surprising was the lack of a significant relationship between body N:P and excretion N:P among species ( $r=-0.509, p=0.302$; Figure 4), although this could be due to the small number of species considered as the pattern of this relationship was in the expected direction.

\section{Discussion}

Identifying the drivers of species-specific variation in consumer stoichiometry and nutrient dynamics is important to elucidate how evolutionary processes affect ecosystem processes. In this study, we found that trophic traits better explained variation in nutrient mineralization stoichiometry than body stoichiometry among species of Panamanian armored catfishes. Prior work has demonstrated that intraspecific, microevolutionary variation in these traits within species can affect nutrient recycling and ecosystem function (e.g., $[8,12,34])$. Our results provide additional insight, suggesting that at the macroevolutionary scale, trophic traits may also be important drivers of variation.

From a stoichiometric perspective, loricariid catfishes have historically stood out from most other vertebrate groups for their high body $\mathrm{P}$ content and low P excretion rates $[6,21,22]$. While loricariids are typically considered grazers of periphyton and algal detritus, considerable trophic diversity exists within the family [18,35]. We studied six species of loricariids abundant in rivers of Eastern and Central Panama: Rineloricaria uracantha, Sturisoma dariense, and Sturisomatichthys citurensis in the subfamily loricariinae; and Ancistrus chagresi, Chaetostoma fischeri, and Lasiancistrus caucanus in the subfamily hypostominae. Among the loricariines, Rineloricaria is phylogenetically distant from the sister genera Sturisoma and Sturisomatichthys [19,36]. In fact, Covain et al. [36] proposed that all trans-Andean species of Sturisoma (including S. dariense) are actually paraphyletic within Sturisomatichthys and these two species may thus be congeneric. Among the hypostomines, Ancistrus and Lasiancistrus are sister genera, with Chaetostoma occupying a separate clade [19]. In spite of the close relationships among some of the genera we studied, they are all diverse genera distributed primarily throughout the Andes, and their relatives thus diverged prior to colonizing the isthmus of Panama.

Although we only sampled small assemblages of loricariids near the northern extent of their native range, our data were remarkably consistent with phylogenetic patterns in diet observed 
for the Loricariinae from 19 assemblages in the Amazon, Orinoco, and Essequibo basins in South America [18]. As in Panama, Rineloricaria feeds at a lower trophic position than Sturisoma across these assemblages [18]. We also found that within Hypostominae, Ancistrus, Chaetostoma, and Lasiancistrus fed at a similar trophic position but varied in $\delta^{13} \mathrm{C}$, as reported for these genera from the same set of South American assemblages [18]. Further, our stoichiometric results are fairly consistent with those previously published for an Andean piedmont assemblage of loricariids in Venezuela [6]. While that assemblage lacked Sturisoma or Sturisomatichthys, they similarly found that the most P-rich species was sister to those genera, i.e., Farlowella. In addition, Chaetostoma species in both our study and in Vanni et al. [6] were richer in P than their corresponding Ancistrus species. Additional sampling of other loricariid assemblages will improve our understanding of phylogenetic patterns in their traits, but the consistency of our results with previous research suggests that trophic position and stoichiometric traits are relatively conserved phylogenetically within Loricariidae.

In spite of the consistency of our results with prior studies, however, the fact that Sturisoma and Sturisomatichthys exhibited the highest $\delta^{15} \mathrm{~N}$ values of all species contrasted with the phylogenetic patterns observed by Lujan et al. [18]. This discrepancy could be explained by differences in baseline $\delta^{15} \mathrm{~N}$ among sites. While we have no reason to believe that basal resources in the Chucunaque watershed are more $\delta^{15} \mathrm{~N}$-enriched than in the other basins, such a difference could explain our results [36]. Alternatively, this apparent difference from Lujan et al. [18] could also be resolved by recent phylogenetic work in this group. While Lujan et al. [18] only examined cis-Andean species of Sturisoma, Covain et al. [36] hypothesized that trans-Andean Sturisoma (including S. dariense) are paraphyletic with respect to Sturisomatichthys. Therefore, it is possible that species within the trans-Andean Sturisoma/Sturisomatichthys have evolved a more insectivorous diet, or otherwise feed on more protein-rich material than cis-Andean Sturisoma sensu stricto. Historical research on loricariid diets used evidence from variation in gut morphology to suggest most Panamanian loricariine species were more omnivorous than hypostomines and the loricariine Rineloricaria [27]. Collectively, this work suggests that variation in the trophic traits of loricariids is well supported, and coupled with our findings, suggests that trophic traits may be an important driver of interspecific variation in the rates and ratios of nutrient mineralization.

That trophic traits best predicted variation in excretion stoichiometry was not particularly surprising, but the nature of these relationships was unexpected. Specifically, the positive correlation between $\delta^{15} \mathrm{~N}$ and N:P of excretion among species was surprising, given that consumers feeding at higher trophic levels typically consume more P-rich animal prey. According to the tenets of ecological stoichiometry, organisms feeding on a more P-rich diet should then excrete $\mathrm{P}$ at higher rates if all else is equal [4], which in turn leads to a predicted negative relationship between $\delta^{15} \mathrm{~N}$ and excretion $\mathrm{N}: P$. This surprising relationship could be explained by the variability in traits within species and low sample sizes of some species measured. If the average values included in this analysis were biased by small sample sizes or large outliers, we could expect to see a weak or counterintuitive pattern such as the one we observed. Alternatively, our results would be possible if the maximum accumulation efficiency for $\mathrm{P}$ increases with trophic position. Such a scenario could occur if fishes feeding at a higher trophic position consume less food, as reduced consumption rate leads to increased P retention efficiency [12]. Indeed, feeding rate typically decreases when consumers feed on high quality resources (e.g., [37,38]). High feeding rates in algivorous loricariids, relative to those of their insectivorous sister family Astroblepidae, have been proposed as a mechanism explaining how loricariids persist on a diet that is typically depauperate in P despite their high P demand [25]. Further work on this problem is needed to assess the generality of these constraints and whether they explain dietary diversification in and among this diverse family.

The results from this work expand our understanding of how consumer-driven nutrient dynamics vary within assemblages of Panamanian loricariids. However, there are three caveats in our data that are worthy of discussion. First, the use of stable isotope data to approximate trophic traits is well-supported in loricariids [18], but any analysis of trophic traits based on stable isotopes without 
isotopic baseline data must be interpreted with caution [39]. In our case, the alignment of our trophic trait data with isotopic niche data from other species within these genera [18] and with gut morphology of these same species [27] supports our conclusions. However, it is likely that variation in isotopic signatures among watersheds explains some of the variation in trophic traits we ascribe to these species. Second, the small sample sizes limit the interpretation of these data. While we aimed to measure excretion rates of at least 10 individuals of each species, we were only able to do so for three of these species due to time and resource constraints (Table 2). The patterns we observed remain unchanged when the excretion data for the species for which we collected fewer individuals was excluded; however, more data to fully characterize interspecific variation in excretion rates would greatly enhance this dataset. Finally, we did not incorporate variation between sexes or among life stages into our analysis. While little is known of the reproductive biology of many of these species, at least one of our study species, Rineloricaria uracantha, is known to breed year-round [40]. Thus, reproductive adults may invest nutrients differently into eggs or sperm relative to each other or non-reproducing juveniles. Recent work in poeciliid fishes suggests that body and excretion stoichiometry do not vary systematically between sexes [41,42], but whether the same is true of loricariids is not known.

Together, our results lend mixed support to the hypothesis that phylogenetic trait conservatism explains taxonomic patterns in nutrient excretion rates and ratios. Although excretion rates of $\mathrm{N}$ and $\mathrm{P}$, as well as excretion stoichiometry, varied between subfamilies, body stoichiometry did not. Instead, conservatism of trophic traits among genera was the best predictor of excretion rates and stoichiometry. These results underscore the need to examine the degree of phylogenetic conservatism in the traits of interest when considering how the functional role of consumers in ecosystem-scale processes such as nutrient cycling varies among lineages. Shifts in trophic traits are common within many families of fishes (e.g., $[18,43,44])$, but the ecosystem-scale impacts of these macroevolutionary shifts are poorly studied. Our work suggests that explicitly considering the degree and causes of reduced phylogenetic conservatism of trophic traits among functionally important consumer assemblages will yield insights into how evolutionary processes shape geographic patterns in ecosystem functioning across the landscape.

Author Contributions: Conceptualization, E.K.M., F.A., K.A.C., O.P. and B.L.T.; Data curation, B.L.T.; Formal analysis, E.K.M. and B.L.T.; Investigation, E.K.M. and F.A.; Methodology, E.K.M., F.A. and B.L.T.; Resources, O.P.; Supervision, K.A.C.; Writing—original draft, E.K.M.; Writing-review \& editing, E.K.M., F.A., K.A.C., O.P. and B.L.T.

Funding: This work was funded by a STRI-ASU fellowship to EKM.

Acknowledgments: We thank Rigoberto González, Nathan Lujan, Ruth Gisela Reina, Evelyn Ríos, Amanda Rugenski, and Alex Tran for assistance in collecting and identifying fish, and Dayana Agudo and Aleksandra Bielnicka for laboratory support. Jim Elser and John Sabo provided feedback on study design. We thank the Autoridad Nacional del Ambiente (ANAM) of Panamá for issuing permits for this research (permit numbers SC/A-44-12 and SE/A-16-82). The work was approved by the animal use committees at STRI (IACUC protocol \#2013-0104-2016) and ASU (IACUC protocol \#13-1296TK). The community of Peña Bijagual and staff at the Smithsonian Tropical Research Institute provided hospitality and logistical assistance that was critical to this project.

Conflicts of Interest: The authors declare no conflict of interest

\section{References}

1. Vanni, M.J. Nutrient cycling by animals in freshwater ecosystems. Ann. Rev. Ecol. Syst. 2002, 33, 341-370. [CrossRef]

2. McIntyre, P.B.; Flecker, A.S.; Vanni, M.J.; Hood, J.M.; Taylor, B.W.; Thomas, S.A. Fish distributions and nutrient cycling in streams: Can fish create biogeochemical hotspots. Ecology 2008, 89, 2335-2346. [CrossRef] [PubMed]

3. Atkinson, C.L.; Capps, K.A.; Rugenski, A.T.; Vanni, M.J. Consumer-driven nutrient dynamics in freshwater ecosystems: From individuals to ecosystems. Biol. Rev. 2017, 92, 2003-2023. [CrossRef] [PubMed]

4. Sterner, R.W. The ratio of nitrogen to phosphorus resupplied by herbivores: Zooplankton and the algal competitive arena. Am. Nat. 1990, 136, 209-229. [CrossRef] 
5. Sterner, R.W.; Elser, J.J.; Hessen, D.O. Stoichiometric relationships among producers, consumers and nutrient cycling in pelagic ecosystems. Biogeochemistry 1992, 17, 49-67. [CrossRef]

6. Vanni, M.J.; Flecker, A.S.; Hood, J.M.; Headworth, J.L. Stoichiometry of nutrient recycling by vertebrates in a tropical stream: Linking species identity and ecosystem processes. Ecol. Lett. 2002, 5, 285-293. [CrossRef]

7. Evans-White, M.A.; Lamberti, G.A. Stoichiometry of consumer-driven nutrient recycling across nutrient regimes in streams. Ecol. Lett. 2006, 9, 1186-1197. [CrossRef] [PubMed]

8. El-Sabaawi, R.W.; Marshall, M.C.; Bassar, R.D.; López-Sepulcre, A.; Palkovacs, E.P.; Dalton, C. Assessing the effects of guppy life history evolution on nutrient recycling: From experiments to the field. Freshw. Biol. 2015, 60, 590-601. [CrossRef]

9. Allgeier, J.E.; Wenger, S.J.; Rosemond, A.D.; Schindler, D.E.; Layman, C.A. Metabolic theory and taxonomic identity predict nutrient recycling in a diverse food web. Proc. Natl. Acad. Sci. USA 2015, 112, E2640-E2647. [CrossRef]

10. Mather, M.E.; Vanni, M.J.; Wissing, T.E.; Davis, S.A.; Schaus, M.H. Regeneration of nitrogen and phosphorus by bluegill and gizzard shad: Effect of feeding history. Can. J. Fish. Aquat. Sci. 1995, 52, 2327-2338. [CrossRef]

11. Moody, E.K.; Corman, J.R.; Elser, J.J.; Sabo, J.L. Diet composition affects the rate and N:P ratio of fish excretion. Freshw. Biol. 2015, 60, 456-465. [CrossRef]

12. Moody, E.K.; Carson, E.W.; Corman, J.R.; Espinosa-Pérez, H.; Ramos, J.; Sabo, J.L.; Elser, J.J. Consumption explains intraspecific variation in nutrient recycling stoichiometry in a desert fish. Ecology 2018, 99, 1552-1561. [CrossRef] [PubMed]

13. McManamay, R.A.; Webster, J.R.; Valett, H.M.; Dolloff, C.A. Does diet influence consumer nutrient cycling? Macroinvertebrate and fish excretion in streams. J. N. Am. Benthol. Soc. 2011, 30, 84-102. [CrossRef]

14. Böhning-Gaese, K.; Oberrath, R. Phylogenetic effects on morphological, life-history, behavioural and ecological traits of birds. Evol. Ecol. Res. 1999, 1, 347-364.

15. González, A.; Céréghino, R.; Dézerald, O.; Farjalla, V.F.; Leroy, C.; Richardson, B.A.; Richardson, M.J.; Romero, G.Q.; Srivastava, D.S. Ecological mechanisms and phylogeny shape invertebrate stoichiometry: A test using detritus-based communities across Central and South America. Funct. Ecol. 2018, 32, 2448-2463. [CrossRef]

16. Losos, J.B. Phylogenetic niche conservatism, phylogenetic signal and the relationship between phylogenetic relatedness and ecological similarity among species. Ecol. Lett. 2008, 11, 995-1007. [CrossRef] [PubMed]

17. Olalla-Tárraga, M.A.; González-Suárez, M.; Bernardo-Madrid, R.; Revilla, E.; Villalobos, F. Contrasting evidence of phylogenetic trophic niche conservatism in mammals worldwide. J. Biogeogr. 2017, 44, 99-110. [CrossRef]

18. Lujan, N.K.; Winemiller, K.O.; Armbruster, J.W. Trophic diversity in the evolution and community assembly of loricariid catfishes. BMC Evol. Biol. 2012, 12, 124. [CrossRef]

19. Lujan, N.K.; Armbruster, J.W.; Lovejoy, N.R.; López-Fernández, H. Multilocus molecular phylogeny of the suckermouth armored catfishes (Siluriformes: Loricariidae) with a focus on subfamily Hypostominae. Mol. Phylogenet. Evol. 2015, 82, 269-288. [CrossRef]

20. Meek, S.E.; Hildebrand, S.F. The fishes of the fresh-waters of Panama. Field Mus. Nat. Hist. Zool. Ser. 1916, 10, 217-374.

21. Hood, J.M.; Vanni, M.J.; Flecker, A.S. Nutrient recycling by two phosphorus-rich grazing catfish: The potential for phosphorus-limitation of fish growth. Oecologia 2005, 146, 247-257. [CrossRef] [PubMed]

22. McIntyre, P.B.; Flecker, A.S. Ecological stoichiometry as an integrative framework in stream fish ecology. Am. Fish. Soc. Symp. 2010, 73, 539-558.

23. Capps, K.A.; Flecker, A.S. Invasive aquarium fish transform ecosystem nutrient dynamics. Proc. R. Soc. B 2013, 280, 2013520. [CrossRef] [PubMed]

24. Capps, K.A.; Flecker, A.S. Invasive fishes generate biogeochemical hotspots in a nutrient-limited system. PLoS ONE 2013, 8, e54093. [CrossRef] [PubMed]

25. Moody, E.K.; Lujan, N.K.; Roach, K.A.; Winemiller, K.O. Threshold elemental ratios and the temperature-dependence of herbivory in fishes. Funct. Ecol. 2019, 33, 913-923. [CrossRef]

26. Albert, J.S.; Lovejoy, N.R.; Crampton, W.G.R. Miocene tectonism and the separation of cis- and trans-Andean river basins: Evidence from Neotropical fishes. J. S. Am. Earth Sci. 2006, 21, 14-27. [CrossRef] 
27. Pineda, E. Aspectos de la Biología, Ecología, y Distribución de la Familia Loricariidae (Chupapiedras) en la Cuenca del Río Bayano. Ph.D. Thesis, Tésis de Licenciatura, Universidad de Panamá, Ciudad de Panamá, Panama, 1976.

28. Angermeier, P.L.; Karr, J.R. Fish communities along environmental gradients in a system of tropical streams. Environ. Biol. Fishes 1983, 9, 117-135. [CrossRef]

29. Power, M.E. Habitat quality and the distribution of algae-grazing catfish in a Panamanian stream. J. Anim. Ecol. 1984, 1984, 357-374. [CrossRef]

30. Small, G.E.; Pringle, C.M.; Pyron, M.; Duff, J.H. Role of the fish Astyanax aeneus as a keystone nutrient recycler in low-nutrient Neotropical streams. Ecology 2011, 92, 386-397. [CrossRef]

31. Lujan, N.K.; German, D.P.; Winemiller, K.O. Do wood-grazing fishes partition their niche? Morphological and isotopic evidence for trophic segregation in Neotropical Loricariidae. Funct. Ecol. 2011, 25, 1327-1338. [CrossRef]

32. Post, D.M.; Layman, C.A.; Arrington, D.A.; Takimoto, G.; Quattrochi, J.; Montaña, C. Getting to the fat of the matter: Models, methods and assumptions for dealing with lipids in stable isotope analyses. Oecologia 2007, 152, 179-189. [CrossRef] [PubMed]

33. R Core Team. R: A Language and Environment for Statistical Computing; R Foundation for Statistical Computing: Vienna, Austria, 2018; Available online: http://www.R-project.org/ (accessed on 30 March 2019).

34. Bassar, R.D.; Marshall, M.C.; López-Sepulcre, A.; Zandonà, E.; Auer, S.K.; Travis, J.; Pringle, C.M.; Flecker, A.S.; Thomas, S.A.; Fraser, D.F.; et al. Local adaptation in Trinidadian guppies alters ecosystem processes. Proc. Natl. Acad. Sci. USA 2010, 107, 616-3621. [CrossRef] [PubMed]

35. Lujan, N.K.; Armbruster, J.W. Morphological and functional diversity of the mandible in suckermouth armored catfishes (Siluriformes, Loricarioidea). J. Morphol. 2012, 273, 24-39. [CrossRef] [PubMed]

36. Covain, R.; Fisch-Muller, S.; Oliveira, C.; Mol, J.H.; Montoya-Burgos, J.I.; Dray, S. Molecular phylogeny of the highly diversified catfish subfamily Loricariinae (Siluriformes, Loricariidae) reveals incongruences with morphological classification. Mol. Phylogenet. Evol. 2016, 94, 492-517. [CrossRef] [PubMed]

37. Raubenheimer, D.; Simpson, S.J. The geometry of compensatory feeding in the locust. Anim. Behav. 1993, 45, 953-964. [CrossRef]

38. Jochum, M.; Barnes, A.D.; Ott, D.; Lang, B.; Klarner, B.; Farajallah, A.; Scheu, S.; Brose, U. Decreasing stoichiometric resource quality drives compensatory feeding across trophic levels in tropical litter invertebrate communities. Am. Nat. 2017, 190, 131-143. [CrossRef]

39. Post, D.M. Using stable isotopes to estimate trophic position: Models, methods, and assumptions. Ecology 2002, 83, 703-718. [CrossRef]

40. Moodie, G.E.E.; Power, M.E. The reproductive biology of an armoured catfish, Loricaria uracantha, from Central America. Environ. Biol. Fishes 1982, 7, 143-148.

41. El-Sabaawi, R.W.; Zandonà, E.; Kohler, T.J.; Marshall, M.C.; Moslemi, J.M.; Travis, J.; López-Sepulcre, A.; Ferriére, R.; Pringle, C.M.; Thomas, S.A.; et al. Widespread intraspecific organismal stoichiometry among populations of the Trinidadian guppy. Funct. Ecol. 2012, 26, 666-676. [CrossRef]

42. Ambus, N.; Moody, E.K. Size-based sexual dimorphism of nitrogen excretion in livebearing fishes. Ecol. Freshw. Fish 2019, 28, 222-228. [CrossRef]

43. German, D.P.; Nagle, B.C.; Villeda, J.M.; Ruiz, A.M.; Thomson, A.W.; Contreras Balderas, S.; Evans, D.H. Evolution of herbivory in a carnivorous clade of minnows (Teleostei: Cyprinidae): Effects on gut size and digestive physiology. Physiol. Biochem. Zool. 2009, 83, 1-18. [CrossRef] [PubMed]

44. Martin, C.H.; Wainwright, P.C. Trophic novelty is linked to exceptional rates of morphological diversification in two adaptive radiations of Cyprinodon pupfishes. Evolution 2011, 65, 2197-2212. [CrossRef] [PubMed]

(C) 2019 by the authors. Licensee MDPI, Basel, Switzerland. This article is an open access article distributed under the terms and conditions of the Creative Commons Attribution (CC BY) license (http://creativecommons.org/licenses/by/4.0/). 